Proceedings of SALT 28: 141-160, 2018

\title{
Definiteness in Akan: Familiarity and uniqueness revisited*
}

\author{
Carla Bombi \\ Universität Potsdam
}

\begin{abstract}
In the recent semantic literature, Akan is viewed as a language which, like German, distinguishes between uniqueness definites and familiarity definites (Schwarz 2009, 2013), following a proposal by Arkoh \& Matthewson (2013). Based on a re-examination of previous evidence and on novel fieldwork data, this paper argues that this distinction is not supported in Akan. A novel analysis is put forward, according to which the Akan overt determiners have instead a distribution similar to that of English the and that. Differences between English the and the Akan article nó are attributed to the availability of a definite bare noun, which is a competitor to the overt definite in Akan. The paper shows that definiteness distinctions cannot always be reduced to a uniqueness-familiarity dichotomy, and points to a more articulated view of definites cross-linguistically.
\end{abstract}

Keywords: definiteness, uniqueness, familiarity, Akan, fieldwork semantics

\section{Introduction}

The recent semantic literature distinguishes between two types of definites crosslinguistically: uniqueness definites (which presuppose uniqueness) and familiarity definites (which presuppose an overt antecedent) (Schwarz 2009, 2013; Jenks 2015, 2018; Grubic 2015; Ingason 2016). This distinction, originally posited by Schwarz (2009) on the basis of German, is supported by the fact that some languages morphologically distinguish the two definiteness types, in addition to separately encoding a demonstrative. One well-known example of such a language is Akan (Kwa, NigerCongo): in a previous formal analysis, Arkoh \& Matthewson (2013) argue that the article nó encodes familiarity, while the bare noun expresses uniqueness. As one of the first languages to which the analysis was extended, Akan has become a paradigmatic example supporting Schwarz's (2009) division of the definiteness space.

* This paper presents revised material from my Master's thesis. I would like to thank Malte Zimmermann and Radek Šimík for their insightful supervision and encouragement. I would also like to thank Joseph P. De Veaugh-Geiss, Mira Grubic, Paul Mätzig, and Agata Renans for discussion of the materials and for comments. Thanks also to Reggie Duah for his help during my stay in Accra, and for his patience in responding to my Akan consultations. Above all, thanks to all the consultants that have made this work possible. All errors are mine.

C2018 Bombi 
Contrary to Arkoh \& Matthewson, this paper argues that Schwarz's system is not supported in Akan. Based on fieldwork data, a novel analysis of Akan definites is presented, which relies on two key ingredients. First, rather than encoding a contrast between uniqueness and familiarity, Akan overtly distinguishes between uniqueness and direct referentiality (Simonenko 2014). This distinction captures the distribution of the overt determiners in this language - the definite article nó and the distal demonstrative sàá...nó-which are found in the same core uses as English the and that. Second, some differences between Akan nó and English the are attributed to competition principles: unlike English, Akan has a bare noun which can receive definite construals, and which is a structural and pragmatic competitor to nó. From a broader perspective, the analysis shows that there is more variation in the realm of definiteness than is assumed in the cross-linguistic literature. It further raises the question of how to integrate a formal implementation of these definiteness systems into a coherent typological picture.

The paper is laid out as follows. Section 2 presents the relevant background literature, which comprises Schwarz's theory and Arkoh \& Matthewson's analysis of Akan definites. Section 3 discusses and formally analyzes the overt determiners in this language, which are shown not to fall into the uniqueness/familiarity dichotomy, but rather into the uniqueness/direct referentiality one. Section 4 discusses the alternation between nó and the bare noun. Section 5 briefly concludes.

Before turning to the main discussion, this section closes with some information on Akan and the methodology used in data collection. Akan (Kwa, Niger-Congo) is a group of mutually intelligible dialects spoken by approximately 8.3 million people (Lewis, Simons \& Fennig 2018) predominantly in the southern half of Ghana. The fieldwork data presented in Section 3 and 4 come from the Asante Twi dialect of the language (2.8 million speakers). Asante Twi, like the other major varieties of Akan, is taught in schools in regions in which it is spoken as a native language (Duah 2013). It further has its own standard orthography, which will adopted for the examples in this paper. ${ }^{1}$ Akan distinguishes between high (') and low (') tones, and its basic word order is SVO. The data in Sections 3 and 4 stem from the author's own fieldwork with primarily five speakers of Akan (Asante Twi dialect), conducted in 2017-2018 in Accra, Ghana, and Berlin/Potsdam. The data were gathered following the guidelines for semantic fieldwork presented in Matthewson 2004, and the tasks used where translation and acceptability judgments in a linguistic context.

1 Arkoh \& Matthewson (2013) base their paper on the Fante dialect of Akan, but they also provide some Asante Twi examples. The literature reports no differences in the definiteness systems of these two varieties, except for the form—but not uses—of the distal demonstrative: sàá...nó in Asante Twi, but dén...nó in Fante (see, e.g., Amfo 2007). Further notational differences between the examples in Arkoh \& Matthewson 2013 and the ones presented here are due to the fact that they use an IPA transcription rather the standard Akan orthography. 


\section{Previous literature}

This section presents Schwarz's (2009) approach to definites, and Arkoh \& Matthewson's (2013) application thereof to Akan. It is argued that Arkoh \& Matthewson's data are insufficient to support their analysis based on Schwarz's distinctions.

\subsection{Schwarz (2009): two types of definites}

Schwarz's (2009) theory was originally developed on the basis of an alternation found in a number of West Germanic varieties (including Standard German and Fering - a Northern Frisian dialect). As presented in Schwarz 2009, the peculiarity about these varieties is that they make a morphological distinction in the domain of definiteness that is not found in English, between so-called strong articles (or "familiarity definites"), and weak articles ("uniqueness definites"). ${ }^{2}$ In Standard German, this contrast becomes apparent in sequences of prepositions followed by a determiner. In these contexts, and granted that certain morphological and information structural restrictions are met, the sequence contracts to a portmanteau morpheme with the uniqueness definite ( $z$ u dem $\rightarrow$ zum, in dem $\rightarrow$ im, an dem $\rightarrow$ am); by contrast, it remains uncontracted with the familiarity definite.

Turning to their distribution, uniqueness definites, but not familiarity definites, are found in contexts that, as their name indicate, can be subsumed under the label of "uniqueness". This label encompasses, for the most part, so-called "situational uses" (Hawkins 1978) — contexts in which the definite expression refers to an entity in the external world, which is unique in a certain situation in bearing the nominal property. In immediate situation uses, the entity in question is immediately perceptible:

Das Buch, das du suchst, steht im / \# in dem Glasschrank.

the book that you look-for stands in-the weak $_{\text {/ in the }}$ strong glass-cabinet 'The book that you are looking for is in the glass-cabinet.'

German (Schwarz 2009: 39)

Another situational use are larger situations. These uses rely on world knowledge, rather than direct perception, as the entity in question is not present in the utterance context: the interlocutors have to know that a certain larger situation (e.g., a town) typically contains a unique entity of a certain type (e.g., a mayor), as in (2):

Der Empfang wurde vom / \# von dem Bürgermeister eröffnet.
the reception was by-the weak $_{\text {/ by the }}$ strong mayor opened

'The reception was opened by the mayor.' German (Schwarz 2009: 40)

2 Jenks 2018 uses the term "anaphoric definite" instead of "familiarity definite". Although this term is more explicit about the environments in which the determiner is found, here we follow Arkoh \& Matthewson (2013) in using "familiarity" to facilitate the comparison between the two approaches. 
A special case of larger situation involves reference to globally unique entities, such as the sun or the moon, where the larger situation in question is the world:

\section{(3) Armstromg flog als erster zum Mond.}

Armstromg flew as first.one to-the weak $_{\text {moon }}$

'Armstrong was the first one to fly to the moon.' German (Schwarz 2009: 40)

Finally, beyond situational uses, another uniqueness environment is (part-whole) bridging - reference to an entity which has not been mentioned in previous discourse, but whose presence and uniqueness can be deduced by world knowledge-as happens, for instance, in part-whole relations (e.g., crisper-fridge): ${ }^{3}$

Der Kühlschrank war so groß, dass der Kürbis problemlos

The fridge was so big that the pumpkin without-a-problem

im / \# in dem Gemüsefach untergebracht werden konnte.

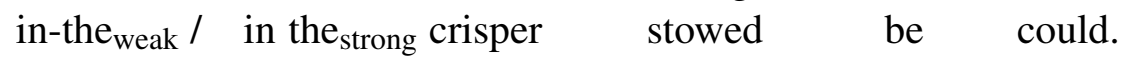

'The fridge was so big that the pumpkin could easily be stowed in the crisper.'

German (Schwarz 2009: 52)

On the other hand, familiarity definites, but generally not uniqueness definites, are found in anaphoric contexts, i.e., with reference to a previously mentioned entity:

Bei der Gutshausbesichtigung hat micheines der Zimmer besonders

During the mansion.tour has me one the GEN $_{\text {rooms especially }}$ beeindruckt. Angeblich hat Goethe im Jahr 1810 eine Nacht \#

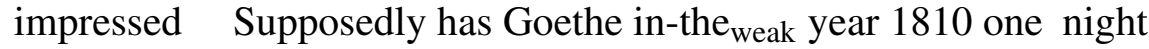

im / in dem Zimmer verbracht.

in-the weak $_{\text {/ }}$ in the strong $_{\text {room spent }}$

'One of the rooms especially impressed me during the mansion tour. Supposedly Goethe spent a night in the room in 1810.'

German (Schwarz 2009: 42)

Based on this dissociation, Schwarz proposes that two semantic mechanisms for definiteness should be distinguished, one per determiner:

$$
\begin{aligned}
& \llbracket D_{\text {unique }} \rrbracket=\lambda \mathrm{s} . \lambda \mathrm{P}: \exists ! \mathrm{x}\left(\mathrm{P}(\mathrm{x})\left(\mathrm{s}_{\mathrm{r}}\right)\right) . \imath \mathrm{x}\left[\mathrm{P}(\mathrm{x})\left(\mathrm{s}_{\mathrm{r}}\right)\right] \\
& \llbracket D_{\text {familiar }} \rrbracket=\lambda \mathrm{s} \cdot \lambda \mathrm{P} \cdot \lambda \mathrm{y}: ! \exists \mathrm{x}\left[\mathrm{P}(\mathrm{x})\left(\mathrm{s}_{\mathrm{r}}\right) \wedge \mathrm{x}=\mathrm{y}\right] . \imath \mathrm{x}\left[\mathrm{P}(\mathrm{x})\left(\mathrm{s}_{\mathrm{r}}\right) \wedge \mathrm{x}=\mathrm{y}\right]
\end{aligned}
$$

3 According to Schwarz, there is a second kind of bridging, the so-called "relational bridging", which is characteristic of the familiarity definite. This paper will not discuss relational bridging in detail, since the definite in this use is assigned a modified definition, complicating the argumentation. However, the presence of a potential relational antecedent will be controlled for in the relevant examples. See also discussion in Section 3.1. 
As defined in (6), the uniqueness definite essentially encodes $\imath$, which comes with a uniqueness presupposition. The definition is complemented by a domain restriction system based on Kratzer's (1989) situation semantics: uniqueness holds within the resource situation $s_{r}$, which is picked out by a syntactically represented situation pronoun at DP-level. Overall, the uniqueness presupposition as implemented here aims to capture the "uniqueness uses" of the determiner. In turn, the familiarity definite incorporates a referential index (represented by $y$ ) in addition to $t$. The determiner presupposes that the unique individual in $s_{r}$ with the nominal property $\mathrm{P}$ has to be identical to some salient entity $y$. If this presupposition is satisfied, the expression returns that individual. This condition is met in cases of anaphora-which supply an antecedent that can be picked out by the referential index-but not in situational uses and (part-whole) bridging, which do not supply such an antecedent.

Although Schwarz's work focuses on uniqueness and anaphora, he also identifies a third definiteness category: the demonstrative use or deixis, i.e. reference to an external entity by means of pointing. In these uses, the uncontracted form also characteristic of familiarity definites is found in German. Schwarz is unclear about the status of the deixis and its relationship with demonstratives-the determiner traditionally associated with this use-leading to differing interpretations in the subsequent literature. Some authors treat the familiarity definite and the demonstrative as the same semantic object (Simonenko 2014; Jenks 2015; Šimík 2016; see also Elbourne's (2008) treatment of English demonstratives). Others (Ahn 2017) argue that deixis ('exophoricity' in her terminology) is a separate category, based on crosslinguistic evidence. Her argumentation also follows up on Schwarz (2009: §2.2.2.3), who sets demonstrative uses of the familiarity definite apart, observing that here the determiner is usually accented and used in combination with pointing.

Incorporating Ahn's modifications, Schwarz's theory can be summarized as involving three definiteness categories: uniqueness (corresponding to the uniqueness definites), familiarity (corresponding to the German familiarity definite), and deixis (often associated with the demonstrative). The focus of the literature is on the first two categories, which are sometimes assumed to co-exist with the third one (deixis). Table 1 shows an overview of this system, reconstructing the (sometimes implicit) discussion about demonstratives and their relation to deixis.

\begin{tabular}{|c|c|c|c|}
\hline Determiner & UNIQUENESS & FAMILIARITY & ?DEMONSTRATIVE \\
\hline Use & $\begin{array}{cc}\begin{array}{c}\text { situational } \\
\text { uses }\end{array} & \begin{array}{c}\text { (part-whole) } \\
\text { bridging }\end{array} \\
\end{array}$ & anaphora & deixis \\
\hline German & $i m$ & in dem & in $D E M$ \\
\hline
\end{tabular}

Table 1 Distribution of German definites, based on Schwarz 2009. 


\subsection{Arkoh \& Matthewson (2013) on Akan definites}

In a previous formal account of Akan definites, Arkoh \& Matthewson (2013) present this language as supporting Schwarz's categorizations. Indeed, the main claim of the paper is that nó (nơ in their transcription) is a "familiar definite article", a category which the authors eventually assign the denotation of the familiarity definite in (7). Further, the Akan bare noun-an underspecified form which can be indefinite but also definite-is said to perform the function of a uniqueness determiner. Finally, a third form is briefly discussed, namely the distal sàá...nó, which does not receive a formal definition, but which appears to perform the role of the deictic determiner/demonstrative in Schwarz's system. This section re-examines Arkoh \& Matthewson's proposal, and shows that the data they present are inconclusive to justify their analysis adopting Schwarz's theory.

The core of the problem is theoretical: the authors assign no the denotation of the familiarity definite, i.e., the definition in (7). However, they assume that the criterion that satisfies its presupposition is familiarity in Roberts's (2003) sense (simplifying for the purposes of argumentation: an existence presupposition), rather than familiarity in Schwarz's sense (a strict anaphoricity requirement, for which an overt antecedent is needed). Although this is a technical possibility-the definition simply requires a salient entity with which the NP property can co-refer-this weakening move is problematic. As we have seen, familiarity definites as per Schwarz are a subtype of definites, found only in certain definite contexts (anaphora). On the other hand, familiarity in the way Roberts (2003) — following Heim (1982) uses it is a defining characteristic of all definites. Put differently, the line Roberts's familiarity draws is not between different types of definiteness, but rather between definiteness and indefiniteness. That this notion is not relevant to diagnose Schwarz's familiarity is evidenced by some of Arkoh \& Matthewson's examples, such as (8) below, which involve a definite/indefinite pair.

$$
\begin{aligned}
& \text { a. Kòfí hú-ù òtòmfư nư. } \\
& \text { Kofi see-PAST blacksmith DEF } \\
& \text { 'Kofi saw the blacksmith.' } \\
& \text { b. Kòfí hú-ù òtòmfứ. } \\
& \text { Kofi see-PAST blacksmith } \\
& \text { 'Kofi saw a blacksmith.' }
\end{aligned}
$$

(Arkoh \& Matthewson 2013: 11)

This minimal pair is presented as evidence that nó expresses familiarity: (8a) is only possible if the blacksmith in question is known to the interlocutors, otherwise the indefinite bare noun in (8b) has to be used. However, as can be seen in the indefinite translation of the bare noun, the criterion applied (i.e., the question whether the entity is known) seems to be teasing apart definites from indefinites, which is not the 
evidence needed to show that nó is a familiarity definite in Schwarz's (2009) sense. Another way of evaluating the consequences of this theoretical issue is to consider the evidence that would be required to support Schwarz's theory. Following the description in the previous section, familiarity definites are delimited from uniqueness on the one hand, and demonstratives on the other. Thus, in order to argue that nó is a familiarity definite, one needs to show that it can be used in anaphora (positive evidence) and in no other context (negative evidence). On the one hand, Arkoh \& Matthewson present clear positive evidence for the anaphoricity of nó, as in (9):

Mò-tó-ò èkùtú. Èkùtú \# (nơ) yè dèw pápá. 1SG-buy-PAST orange orange FAM be nice good 'I bought an orange. The orange was nice.'

(adapted from Arkoh \& Matthewson 2013: 2)

However, their negative evidence is not convincing. Starting with uniqueness, nó is said to be incompatible with unique entities such as the moon (Arkoh \& Matthewson 2013: 11), but no examples are presented to support this claim. On the contrary, there are even cases that seem to contradict it, such as (10) below:

òkàsàmáfó nó bé-bá séèséí árá, éntí yé-n-twéń kàkŕá.
speaker DEF FUT-come now just so we-IMP-wait little
'The speaker will arrive soon, so let's wait a little while.'

(Amfo 2007: 146 as cited in Arkoh \& Matthewson 2013: 12)

This example (uttered at a talk) seems to involve a larger situation use, parallel to (2), from which familiarity definites in German are consistently excluded, and in which only uniqueness definites are found. Analogous observations can be made for an example involving a priest at a church service (Arkoh \& Matthewson 2013: 12).

Turning to the delimitation from the demonstrative, Arkoh \& Matthewson do not show that nó cannot be used in deixis-more specifically, deixis examples are generally missing. What is more, the demonstrative is only discussed in connection to an anaphora example, where both nó and sàá...nó can be used. So, there is no evidence regarding a possible differentiation between the two determiners.

What about the bare noun? To support an analysis as a uniqueness definite one has to show that it can be used in uniqueness uses, and nowhere else. At first blush, Arkoh \& Matthewson seem to provide the relevant examples: the bare noun is shown to combine with unique entities such as the moon (globally unique) or the market (unique in a town situation), while it is ruled out in an anaphora example (9) above. However, this definite bare noun is never shown in subject position-indeed, Arkoh \& Matthewson (2013: 12, fn. 19) comment that it is not always permitted in this position - and most of the examples involve a motion verb. 
Considering these syntactic and (possibly) lexical restrictions, it is unclear whether we are dealing with a generalized definite import of the bare noun, or whether the alleged uniqueness examples aren't instead pseudo-incoporating or weak definite constructions (plausible, for instance, for an example involving the expression go to the market, Arkoh \& Matthewson 2013: 12).

In sum, although Akan is often presented as a language supporting Schwarz's definiteness system, Arkoh \& Matthewson's data are not conclusive in this respect. Considering the problems of the analysis, a re-investigation of the Akan determiners is in order.

\section{Overt determiners in Akan: data and analysis}

This section presents and analyzes novel fieldwork data on Akan definites. Rather than focussing on the bare noun, which is ambiguous between definite and indefinite readings, and for which a complex interaction of type-shifting restrictions are expected to apply (Chierchia 1998; Dayal 2004), the investigation focuses on two overt determiners: nó (the alleged familiarity definite) and sàá...nó (the distal demonstrative). ${ }^{4}$ The main empirical generalization, presented in Section 3.1, is that they do not pattern with the definiteness categories identified in Section 2.1. Rather, they have the same uses as the and that in English - a language which does not distinguish morphologically between uniqueness, familiarity, and deixis. In Section 3.2 , their distribution is captured by appealing to the notions of direct referentiality and uniqueness, and formalized building on Schwarz's definitions.

\subsection{Data}

Starting with nó, the determiner is found in uses that are typical of both familiarity definites and uniqueness definites. On the one hand, it can be used in anaphora, in line with Arkoh \& Matthewson's observations:

Mè-tò-ò àtààdéć bí ńnórà. Àtààdéé nó yé fè.
1SG-buy-PST dress INDF yesterday. Dress DEF COP nice
'I bought a dress yesterday. The dress is nice.'

Kofi hù-ù mààmé né àbráńtéć. Àbráńtéé nó kyèá-à Kofi. Kofi see-PST woman COORD young.man. Young.man DEF greet-PST Kofi 'Kofi saw a woman and a boy. The boy greeted Kofi.'

4 Akan also has two proximal demonstratives: the simplex yí and the morphologically complex sàá...yí, which are not discussed for reasons of space (see, e.g. Amfo 2007 for overview). In terms of distribution, both behave like sàá...nó when adjusting for the proximity parameter, and unlike nó. 
However, nó is also found in a number of uniqueness uses. First, it may occur in larger situations:

(13) Context: There is a new teacher at a school. A colleague is explaining to him how everything works. This is the beginning of the conversation, and the colleague explains to the new teacher:

Headmaster nó bé-má wò timetable. headmaster DEF FUT-give 2SG timetable

'The headmaster will give you a timetable.'

(14) Context: Yesterday was the Ghanaian national day and there were a lot of celebrations in Accra, which were visited by one president and many ministers. You go back to your village and talk to your friend about how beatiful the celebration was (but you don't talk about who was there). Your friend asks you whether you saw anyone famous. You say:

j̀màǹpàníń nó bà-àyè.

president DEF come-PST

'The president came.' $\quad$ (context adapted from Renans 2016: 28)

In (13), the interlocutors know by world knowledge that there is only one headmaster in a school situation, and the noun can be combined with nó. The same reasoning applies to (14), where the president is unique within a country. That uniqueness is the factor licensing nó in these examples is supported by the fact that entities that are typically found in the situation, but are not unique in it, cannot be combined with the determiner. However, they are acceptable with the indefinite bí:

(15) Same context as (13).

j̀kyèrèkyérèní \# nó / bí bé-má wò timetable. teacher DEF / INDF FUT-give 2SG timetable

'\#The / A teacher will give you a timetable.'

Comment: [with reference to nó-variant] There are a lot of teachers, so you can't know which one.

(16) Same context as (14).

òsòáfój \# nó / bí bà-àyè.

minister DEF / INDF come-PST

'\#The/A minister came.' 
Nó can also be used with reference to globally unique entities:

(17) Context: Afia is sitting on a bus, when a woman she doesn't know sits down beside her. The woman says:

Àwì̀ nó ré-bò ènné.

sun DEF PRG-hit today

'The sun is shining today."

(context adapted from Barlew 2014: 627)

(18) Context: Amma is outside reading a book. A stranger comes to her and says:

Bósómé nó épíé.

moon DEF fall

'The moon is shining.'

(context adapted from Grubic 2015: 127)

Further, nó is found in immediate situation uses. An indicator of uniqueness is that the determiner is unacceptable if the situation contains several individuals with the property in question, as in (19b).

(19) a. Context: Kofi and Amma are in the market. Amma disappears and comes back with one dress in her hands. Kofi says:

Mè-pè àtààdéé nó.

1SG-like dress DEF

'I like the dress.'

b. Context: Kofi and Amma are in the market. Amma disappears and comes back with several dresses in her hands.

$\Rightarrow$ nó is not possible in this context.

Comment: If you want to point and choose one, you have to bring in the "sàá" [i.e., use the demonstrative sàá...nó].

Finally, nó is found in (part-whole) bridging:

Akua yè ókyèrèkyérèni énà ó-á-nyá àdwúmá fófòró. èdá á

Akua COP teacher COORD 3SG-PFV-get job new day REL

غ̀-dí káń nó, headmaster nó mà-à nò àkwáàbà.

3SG-eat first DEF headmaster DEF give-PST 3SG.OBJ welcome

'Akua is a teacher and she got a new job. On her first day, the headmaster welcomed her.'

Note that the above example could not involve a case of "relational bridging", which according to Schwarz is characteristic of the familiarity definite. In this use, the presupposition of the familiarity determiner is satisfied by a special kind of antecedent, the so-called "relational antecedent", which is the relatum argument 
of producer-produced relations (e.g., book for author). In the first sentence of example (20), there is no good candidate for a relatum argument of headmaster, which supports the claim that it is uniqueness (rather than some antecedent) that is licensing $n o ́$ in the second sentence.

Turning to the distal demonstrative, sàá...nó does not fit Schwarz's classifications either. At first, it would appear to be a good candidate for a familiarity definite, as it can be used in anaphora, see (21). ${ }^{5}$

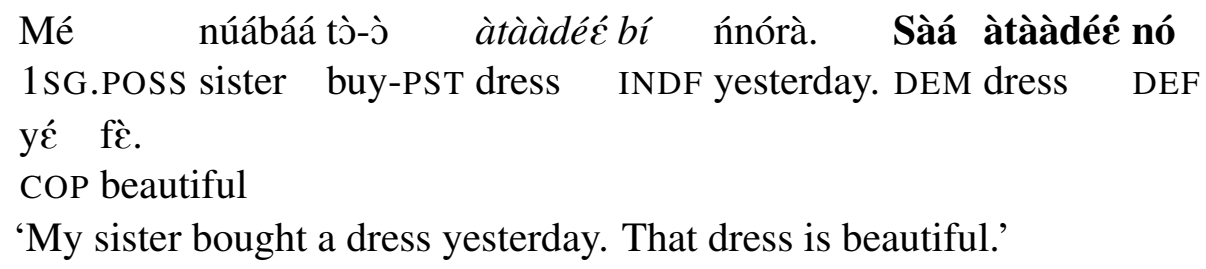

Further, sàá...nó, like the familiarity definite, is ruled out in typical uniqueness contexts: larger situation uses, global situation uses and (part-whole) bridging, at least with a neutral interpretation. Indeed, sàá...nó was rejected in examples (13), (14), (17), (18), and (20). When accepted it seemed to have an affective import, as indicated by the speaker's comment in (22):

\section{(22) Same context as (13).}

\section{\# Sàá headmaster nó bé-má wò timetable. DEM headmaster DEF FUT-give 2SG timetable}

'That headmaster will give you a timetable.'

Comment: You cannot use sàá... nó unless you want to be rude.

However, unlike the familiarity definite, sàá...nó is found in deixis, reference to an entity combined with a pointing gesture. This use is similar to immediate situations, which are characteristic of nó/uniqueness: both contexts involve reference to an individual in the external world-compare the immediate situation example in (19) with deixis in (23) below. However, unlike immediate situations/nó several entities with the same property may be present, as in (23) and (24). Further, the pointing gesture appears to be obligatory, and it disambiguates reference when uniqueness is not satisfied.

(23) Context: Kofi and Amma are in the market. Amma disappears and comes back with one dress / several dresses in her hands. Kofi says:

\section{Mè-pè sàá àtààdéé nó.}

1SG-like DEM dress DEF

5 The example is slightly modified with respect to (11), the nó anaphora example, to make the use of the distal demonstrative more natural. 
'I like that dress [pointing at Amma's dress].'

(24) Context: [The consultant had to express the idea that only one of two cars was nice. The cars were visible to both the speaker and the interviewer and could be pointed at.]

Mè-pè \# (sàá) car nó nàńsó mè-m̀-pé \# (sàá) car nó. 1SG-like DEM car DEF but 1SG-NEG-like DEM car DEF

'I like that car [pointing at Audi] but I don't like that car [pointing at Renault].' Comment: [to the variant with the definite article nó] You like the car but you don't like it? Even if there are two cars, it sounds strange.

Overall, the distribution of the two overt determiners in Akan does not fit into Schwarz's typology. This can be seen by comparing the expected distribution of uniqueness and familiarity definites with that of nó and sàá...nó in Table 2. The main observation is that $n o ́$ cross-classifies the crucial distinction between uniqueness and anaphora that lies at the heart of Schwarz's analysis. In turn, sàá...nó cross-classifies the (more implicit) distinction between anaphora and deixis.

Although this distribution is unexpected in light of Schwarz, it is not unusual in comparison to other languages, such as English. Indeed, the definite article the is recognised in the literature to have a wide range of uses, which, parallel to nó, include both uniqueness contexts (situational uses, bridging) and familiarity contexts (anaphora) (see, for instance, Hawkins 1978; Roberts 2003; a.o.). Similarly, demonstratives such as that are found in anaphora and deixis (Wolter 2006; Roberts 2002), just like sàá...nó. The similarities between the two languages become evident by comparing the Akan examples in the previous section with their English translation: nó is allowed and disallowed whenever the is, just like sàá...nó with that. An overview of the distribution of the two determiner series (Akan vs. English) is found in Table 2 (see also Ahn (2017: 14) for a comparison with more languages).

\begin{tabular}{|c|c|c|c|}
\hline $\begin{array}{l}\text { Determiner } \\
\text { Use }\end{array}$ & \begin{tabular}{cc}
\multicolumn{2}{c}{ UNIQUENESS } \\
$\begin{array}{cc}\text { situational } & \text { (part-whole) } \\
\text { uses } & \text { bridging }\end{array}$
\end{tabular} & $\begin{array}{c}\text { FAMILIARITY } \\
\text { anaphora }\end{array}$ & $\begin{array}{c}\text { ?DEMONSTRATIVE } \\
\text { deixis }\end{array}$ \\
\hline German & im & in dem & in DÉM \\
\hline Akan & \multicolumn{2}{|l|}{ nó } & sàá...nó \\
\hline English & the & & that \\
\hline
\end{tabular}

Table 2 Comparison of the distribution of German, Akan and English definites. 


\subsection{Analysis}

The main generalization of the previous section is that nó and sàá...nó behave more like English definites than like German definites as described in Schwarz 2009. Although their distribution does not cut across the uniqueness/familiarity/(deixis) divide, it is possible to capture their behavior by appealing to the same mechanisms posited by Schwarz. I propose the following denotations:

$$
\begin{aligned}
& \llbracket n o ́ \rrbracket=\lambda \mathrm{s} . \lambda \mathrm{P}: \exists ! \mathrm{x}\left(\mathrm{P}(\mathrm{x})\left(\mathrm{s}_{\mathrm{r}}\right)\right) . \imath \mathrm{x}\left[\mathrm{P}(\mathrm{x})\left(\mathrm{s}_{\mathrm{r}}\right)\right] \\
& \llbracket \text { sàá...nó } \rrbracket=\lambda \mathrm{s} . \lambda \mathrm{P} \cdot \lambda \mathrm{y}: ! \exists \mathrm{x}\left[\mathrm{P}(\mathrm{x})\left(\mathrm{s}_{\mathrm{r}}\right) \wedge \mathrm{x}=\mathrm{y}\right] . \imath \mathrm{x}\left[\mathrm{P}(\mathrm{x})\left(\mathrm{s}_{\mathrm{r}}\right) \wedge \mathrm{x}=\mathrm{y}\right]
\end{aligned}
$$

In (25), the definition of nó is identical to the denotation of the uniqueness definite, see (6). In (26), the definition of sàá...nó is identical to the denotation of the familiarity definite, see (7).

How do these definitions apply to the Akan determiners? For the definite article, the notion of uniqueness is extended to cover not only situational uses, but also anaphora. A sample derivation of a definite NP in an anaphora example-(11), repeated below for convenience-is shown in (28). The syntax adopted is from Schwarz (2009).

Mè-tò-ò àtààdéć bí ńnórà. Àtààdéé nó yé fè. 1SG-buy-PST dress INDF yesterday. Dress DEF COP nice

'I bought a dress yesterday. The dress is nice.'

$$
\llbracket\left[\mathrm{DP}\left[\mathrm{NP} \text { dress ][D nó } \mathrm{s}_{1}\right]\right] \rrbracket^{\mathrm{g}}=\imath \mathrm{x}[\text { dress }(\mathrm{x})(\mathrm{g}(1))]
$$

In (27), the DP àtààdé ́x nó 'the dress' introduces the requirement that the dress in question be unique in a contextually salient situation $\mathrm{g}(1)$. We can take this situation to be the one introduced in the first sentence (put informally), which contains one dress. Traditionally, anaphoric examples such as these were considered problematic for uniqueness theories of definiteness: following an argumentation in Heim 1982, (27) would be acceptable even if several dresses were bought, apparently violating uniqueness. However, I assume with Roberts (2003) that what is crucial to evaluate the uniqueness presupposition of the definite determiner is the information shared by the interlocutors, rather than the actual world. Thus, as long as the dress referred to is the only one whose existence in the relevant situation is entailed by the Common Ground, the uniqueness requirement of the determiner is met, licensing nó in (27).

For sàá...nó, we want to extend the definition to cover not just anaphora, but also deixis. The denotation in (26) encodes the presupposition that there be a salient antecedent with the NP property with which to co-refer. Schwarz assumes that this condition only applies to entities in the previous discourse, which captures the basic use of the familiarity definite, namely anaphora. To capture the distribution of sàá...nó, one can assume instead that the presupposition of the demonstrative 
can be met not just with an anaphoric antecedent, but also with a "deictic" one (see also Simonenko 2014, Šimík 2016, following Elbourne's treatment of the English demonstrative). This means that a determiner with the denotation in (26) can also be used if there is a perceptually salient entity in the extra-linguistic context with the nominal property - the entity which is pointed at in deixis. Below is a sample derivation for a deixis example of the Akan distal DP, as applied to (24) (adapted below).

\section{Mè-pè sàá car nó.}

1SG-like DEM car DEF

'I like that car [pointing at Audi].'

$$
\llbracket\left[\mathrm{DP} 2 \text { sàá }_{1}\left[\mathrm{DP} 1[\mathrm{NP} \text { car }]\left[\mathrm{D} n o ́ \mathrm{~s}_{2}\right]\right]\right] \rrbracket^{\mathrm{g}}=\imath \mathrm{x}[\operatorname{car}(\mathrm{x})(\mathrm{g}(2)) \wedge \mathrm{x}=\mathrm{g}(1)=\text { Audi }]^{6}
$$

Although the same denotations have been used as in Schwarz (2009), it should be made clear that the notions they represent and the uses they cover are different. At this point, it is also necessary to evaluate wether the labels of "familiarity" and "uniqueness" are still appropriate for the Akan (and English) determiners. For nó, "uniqueness" still seems in order, as reference is mediated by a uniqueness presupposition. However, the reader should bear in mind that this term is to be understood in a broader sense than in Schwarz, in that it does not rule out anaphora. On the other hand, the label "familiarity"- - originally coined in connection with anaphora examples (Heim 1982) —is inappropriate for sàá...nó and that, as it suggests a distributional restriction that does not hold for these determiners. Indeed, the crucial aspect of demonstratives in Akan (and English) is not that they are anaphoric, but rather that their reference is "anchored" to an individual via a referential index. In the traditional philosophical literature, and more recently in Simonenko 2014, such "anchoring" has been labeled as "direct referentiality". Following Simonenko (2014), a possible way of characterizing the opposition between nólthe and sàá...nólthat is one between uniqueness and direct referentiality.

\section{Another source of variation: the nó/bare noun alternation}

In the analysis presented in the previous section, Akan has been characterized as a language which draws a line between uniqueness and direct referentiality, just like English. This section presents a point of divergence between English and Akan, which can also be seen as a separate source of cross-linguistic variation in the domain

6 For exposition purposes, I am assuming that sàa is the spellout of the referential index that is part of the definition of the demonstrative, whereas nó is spelling out $l$. Note, however, that the proximal demonstrative in Akan, which appears in the same environments as the distal and which can thus be assumed to involve a similar denotation, can have both a simplex form ( $y i$ ) and a complex one (sàá...yí). Thus, the mapping between form and meaning may be more complex than presented here. 
of definiteness: the use of the bare noun in definiteness contexts. Section 4.1 presents the relevant data, and Section 4.2 discusses the problems they pose to the theoretical literature.

\subsection{Data}

The main empirical generalization is that in Akan, the bare noun is found in a subset of uniqueness uses (where the relevant notion of uniqueness is the one developed in Section 3). Put in simple terms, Akan does not obligatorily insert nó: we find the bare noun in contexts where we would expect the in English.

This generalization concerns mainly larger and global situation uses. Here, nó is in (apparently free) variation with the bare noun, as shown below: ${ }^{7}$

(31) Larger situation: Same context as (13).

Headmaster (nó) bé-má wò timetable.

headmaster DEF FUT-give 2SG timetable

'The headmaster will give you a timetable.'

(32) Global situation: Same context as (17).

Àwì̀ (nó) ré-bò ̀̀nné.

sun DEF PRG-hit today

'The sun is shining today.'

With the elicitation techniques employed, no factor could be identified regulating the insertion of nó. First, adding the determiner did not trigger any affectivity inferences, which the consultants often reported for sàá...nó in the same examples. Second, the use of nó does not appear to be forced by factors such as salience, which has been argued to license definite articles in some languages which also have bare nouns (Bulu, Bantu; Barlew 2014). As defined by Barlew, a salience definite is one that is used if the speaker can assume that the referent is being attended to by the hearer, or is relevant to her aims and goals. In Akan, nó was accepted for the "sun" sentence in (32) in both salience and non-salience contexts (cf. the alternation in (33)) — and the same goes for the bare noun. This suggests that there is no contrast along the salience parameter.

a. Context I (SALIENCE): Afia is on a bus, when a woman she doesn't know sits down beside her. The woman draws the window shade, letting in the sunlight. The woman says...

7 Impressionistic data suggest that the same holds in analogous examples with bridging, but this was not tested systematically. Renans (2016) briefly reports similar data for a definite article/bare noun alternation in $\mathrm{Ga}$, a Kwa language also spoken in Ghana. 
b. Context II (NO SALIENCE): Afia is on a bus, when a woman she doesn't know sits down beside her. The woman says...

$\Rightarrow N o$ and bare noun accepted in both contexts.

In sum, at least based on these criteria, nó and the bare noun appear to be in free alternation in larger/global situational uses. ${ }^{8}$

On the other hand, the bare noun cannot appear in other uses which have been characterized in Section 3 as also involving uniqueness, namely anaphora and immediate situations. Here, nó is obligatory:

Mè-tò-ò àtààdéć bí ńnórà. Àtààdéé \# (nó) yé fè. 1SG-buy-PST dress INDF yesterday dress DEF COP nice Intended: 'I bought a dress yesterday. The dress is nice.'

Same context as (19).

Àtààdéé \# (nó) yé fì.

dress DEF COP nice

Intended: 'The dress is nice.'

\subsection{Discussion}

The data presented in the previous section are unexpected in at least two respects. First, the co-existence of nó and the definite bare noun is unexpected if Chierchia's (1998) Blocking Principle is operative in Akan. Informally, this principle states that type shifts are a "last resort operation" which are blocked if the language in question lexicalizes that type shift. Among other things, this principle explains why a language like English-which on Chierchia's analysis should allow free type-shifting - does not have singular bare nouns with a definite import: the definite article the, which lexicalizes $\imath$, blocks the corresponding covert type shift. The same reasoning should, but does not apply in Akan. Here, the bare noun is available in situational uses, suggesting that the bare NP-usually of type $\langle e, t>-$ can be of type $<\mathrm{e}>$. Assuming that individual reference is brought about by a covert iota type shift, this is unexpected, since the shift should be blocked by nó.

The data in Section 4.1 are also unexpected in light of Maximize Presupposition (Heim 1991; Sauerland 2008; Singh 2011, a.o.). In informal terms, Maximize

8 The bare noun appears to be obligatory in singular kind reference:

(i) Krámáń (\# nó) yè àbóá.

dog DEF COP animal

'The dog is an animal.'

This will not be discussed further, since the focus of the paper is on the definiteness uses presented Section 2.1, but it is another bare noun environment to take into consideration in future research. 
Presupposition states that speakers should "presuppose as much as possible": if two expressions have the same truth-conditional content, the one with the stronger presupposition has to be chosen. Maximize Presupposition captures, for instance, the infelicity of the indefinite article when the uniqueness presupposition of the definite article is met, as in (36) below:

a. \# A sun is shining.

b. The sun is shining.

One could expect a similar contrast to arise in the Akan "sun" examples in (32): in larger situation uses, uniqueness is met, and thus nó should be obligatorily insertedits presupposition being stronger than that of bare noun, an underspecified form which can also be indefinite. What we get, however, is optionality.

While solutions for these problems are left for future research, cross-linguistic considerations suggest that optionality of this kind is not an isolated case. First, similar examples of optionality have been noted — and dealt with—in other languages and linguistic domains. For instance, in order to explain optional past tense in Washo (Hokan/isolate), Bochnak (2016) argues that tenseless sentences do not encode a tense feature, whereas tensed sentences do. This syntactic difference suffices for the two sentence types not to be in competition with one another in the sense relevant for Maximize Presupposition. Mucha (2015) applies the same argumentation to optional tense in Medumba (Grassfields Bantu). Turning to Akan, a similar reasoning could be extended to the nominal domain: assuming that the definite bare noun involves a covert type shift, a D head is not projected, while one is present with nó. Thus, the optionality of the determiner could be explained by the nature of the alternation, namely that of a form (nó) with a "non-form" (the bare noun). What needs to be investigated further is why this explanation only works for larger situations, but not for anaphora or immediate situations, in which nó is obligatory.

Second, and returning to definiteness, the data described here are reminiscent of definiteness splits that have been discussed in the previous literature, which share the idea-implicitly or explicitly — that uniqueness may be lexicalized to different extents across languages. For instance, Löbner's (1985) theory of definiteness is based on the idea that nouns are marked differently for definiteness depending on whether they refer to semantically/prototypically unique entities (sun, Pope, ...) or pragmatically unique ones (chair, adjective, ... ). Similarly, Akan marks nouns which are prototypically unique within a certain situation (those found in larger/global situation uses: sun, headmaster, president, ...) in a different way from circumstantially unique ones (nouns in anaphora/immediate situations: dress, $d o g, \ldots)$ : the former optionally take nó, whereas the latter do so obligatorily. What is more, a number of languages have been reported that show defintieness splits involving bare nouns and overt definite determiners-to mention only a few, Haitian 
Creole (Wespel 2008), Mauritian Creole (Wespel 2008), Ga (Renans 2016), Ngamo (Grubic 2015). Some of these languages have been analyzed as reflecting Schwarz's contrast between uniqueness (bare noun) and familiarity (overt determiner) (see, for instance, Schwarz 2013). However, the analysis of Akan definites presented here opens the possibility that a different kind of contrast may be involved in the bare noun/overt definite alternation, and suggests that a closer look at these languages may also be in order.

\section{Conclusion and Outlook}

This paper presented a new analysis of definiteness in Akan. Contrary to previous claims, it was argued that Schwarz's distinctions between uniqueness, familiarity and deixis are not reflected in this language. Rather, the overt definites in Akan, like those in English, draw a line between uniqueness and direct referentiality. Additionally, the definite article $n o ́$ is in competition with a definite bare noun, which explains why its distribution is not identical to that of English the, even thought the two determiners have the same denotation. This analysis raises some non-trivial questions regarding the position of Akan in the cross-linguistic picture. Some of these questions have already been addressed in Section 4, but further issues also deserve mention. For example, in this paper the same denotation was applied to demonstratives (which are deictic and anaphoric) and to familiarity definites (which are only anaphoric). Since some languages have been argued to have genuinely anaphoric determiners (some Germanic dialects as discussed above, but also Lakhota, Lyons 1999; Hausa, Buba 1997; Korean, Romanian, Ahn 2017) the question arises which kind of principle restricts their uses, which are only a subset of "directly referential" environments. Further work (ongoing) is determining to what extent a type shifting analysis of the bare noun is preferred over one involving an empty D head, and extending the definiteness contexts to a wider range of nouns. While these issues are left for future research, the work presented here provides a step towards a better understanding of the Akan system, and, more generally, of definiteness across languages.

\section{References}

Ahn, Dorothy. 2017. Definite and demonstrative description: A micro-typology. GLOW in Asia XI 33-48.

Amfo, Appia Nana. 2007. Akan demonstratives. 37th Annual Conference on African Linguistics 134-148.

Arkoh, Ruby \& Lisa Matthewson. 2013. A familiar definite article in Akan. Lingua 123. 1-30. doi:10.1016/j.lingua.2012.09.012. 
Barlew, Jefferson. 2014. Salience, uniqueness, and the definite determiner -te in Bulu. Semantics and Linguistic Theory 24. 619-639. doi:10.3765/salt.v24i0.2992.

Bochnak, M. Ryan. 2016. Past time reference in a language with optional tense. Linguistics and Philosphy 29(4). 247-294. doi:10.1007/s10988-016-9191-6.

Buba, Malami. 1997. The deictic particle DI-N in Hausa. African Languages and Cultures 10(1). 29-45.

Chierchia, Gennaro. 1998. Reference to kinds across languages. Natural Language Semantics 6(4). 339-405.

Dayal, Veneeta. 2004. Number marking and (in)definiteness in kind terms. Linguistics and Philosophy 27. 393-450. doi:10.1023/B:LING.0000024420.80324.67.

Duah, Reginald Akuoko. 2013. Force dynamics and causation in Akan. Accra, Ghana: University of Ghana dissertation.

Elbourne, Paul. 2008. Demonstratives as Individual Concepts. Linguistics and Philosophy 31(4). 409-466.

Grubic, Mira. 2015. Focus and alternative sensitivity in Ngamo (West-Chadic). Potsdam, Germany: University of Potsdam dissertation.

Hawkins, J.A. 1978. Definiteness and Indefiniteness: A Study in Reference and Grammaticality Prediction. London: Croom Helm.

Heim, Irene. 1982. The semantics of definite and indefinite noun phrases. Amherst, Massachussets: University of Massachussets Amherst dissertation.

Heim, Irene. 1991. Artikel und Definitheit. In Arnim von Stechow \& Dieter Wunderlich (eds.), Semantics: An International Handbook of Contemporary Research, 487-535. Berlin: De Gruyter.

Ingason, Anton Karl. 2016. Realizing morphemes in the Icelandic Noun Phrase. Philadelphia, Pennsylvania: University of Pennsylvania dissertation.

Jenks, Peter. 2015. Two kinds of definites in numeral classifier languages. Semantics and Linguistic Theory 25. 103-124. doi:10.3765/salt.v25i0.3057.

Jenks, Peter. 2018. Articulated definiteness without articles. Linguistic Inquiry 43(3). doi:10.1162/ling_a_00280.

Kratzer, Angelika. 1989. An investigation of the lumps of thought. Linguistics and Philosophy 5(12). 607-653.

Lewis, M. Paul, Gary F. Simons \& Charles D. Fennig (eds.). 2018. Ethnologue: Languages of the World, eighteenth edition. Dallas, Texas: SIL International. http://www.ethnologue.com.

Löbner, Sebastian. 1985. Definites. Journal of Semantics 4(4). 279-326.

Lyons, Christopher. 1999. Definiteness. Cambridge: Cambridge University Press.

Matthewson, Lisa. 2004. On the methodology of semantic fieldwork. International Journal of American Linguistics 70(1). 369-415.

Mucha, Anne. 2015. Temporal interpretation and cross-lingusitic variation. Potsdam, Germany: Universität Potsdam dissertation. 
Renans, Agata. 2016. A cross-categorial definite determiner: evidence from Ga (Kwa). Semantics and Linguistic Theory (SALT) 26 23-42.

Roberts, Craige. 2002. Demonstratives as definites. In Kees van Deemter \& Roger Kibble (eds.), Information Sharing, 1-48. Stanford, CA: CSLI.

Roberts, Craige. 2003. Uniqueness in definite noun phrases. Linguistics and Philosophy 26. 287-350. doi:10.1023/A:1024157132393.

Sauerland, Uli. 2008. Implicated presupposition. In Anita Steube (ed.), The Discourse Potential of Underspecified Structures, 581-600. Berlin: Mouton De Gruyter. doi:10.1515/9783110209303.4.581.

Schwarz, Florian. 2009. Two Types of Definites in Natural Language. Amherst, Massachussetts: University of Massachusetts Amherst dissertation.

Schwarz, Florian. 2013. Two kinds of definites cross-linguistically. Language and Linguistics Compass 7(10). 534-559. doi:10.1111/lnc3.12048.

Šimík, Radek. 2016. On pragmatic demonstratives: The case of pragmatic discourse anaphora in Czech. In Nadine Bade, Polina Berezovskaya \& Anthea Schöller (eds.), Sinn und Bedeutung 20, 640-657.

Simonenko, Alexandra. 2014. Grammatical ingredients of definiteness. Montreal, Canada: McGill University dissertation.

Singh, Raj. 2011. Maximize Presupposition! and local context. Natural Language Semantics 19(2). 146-168. doi:10.1007/s11050-010-9066-2.

Wespel, Johannes. 2008. Descriptions and their domains. the patterns of definiteness markings in French-related Creoles. Stuttgart, Germany: University of Stuttgart dissertation.

Wolter, Linsey. 2006. That's that: the semantics and pragmatics of demonstrative noun phrases. Santa Cruz, California: University of California Santa Cruz dissertation.

Carla Bombi

Campus Golm, House 14

Karl-Liebknecht-Str. 24/25

14476 Potsdam, Germany

carla.bombi.ferrer@uni-potsdam.de 